IRSH 6I (2016), pp. 75-93 doi:10.1017/S002085901600002X

(C) 2016 Internationaal Instituut voor Sociale Geschiedenis

\title{
Remaking The Making: E.P. Thompson's Reception in Argentina and the Shaping of Labor Historiography*
}

\author{
LUCAS POY \\ Universidad de Buenos Aires - CONICET \\ Pte J. E. Uriburu 950, 60, Ci I I $4 A A D$, Ciudad Autónoma de \\ Buenos Aires, Argentina \\ E-mail: lucaspoy@gmail.com
}

AвSTRACT: This article traces the reception of E.P. Thompson's work in Argentina over the past three decades. It explores the context in which Thompson was read by labor historians as a means to analyse the way in which the country's labor historiography was shaped over this period. It argues that, in the I980s and the I990s, against a context characterized by a crisis of the political left and a downturn in the labor movement, Thompson's appropriation was focused on his critique of Marxist "determinism". While this corresponded to similar developments in other countries, Argentinian labor historiography started to show a different path in the early 2000s, when a tremendous social, political, and economic crisis shook the country. The article concludes that recent developments in labor historiography in Argentina show a different pattern to those seen in the "Global North".

At a conference delivered in Freiburg in 1989, the French sociologist Pierre Bourdieu addressed the German public attending the inauguration of a Center for French Studies by assessing the problem of the "international circulation of ideas". Analysing the way in which intellectual products are disseminated across different regions and periods, Bourdieu argued that "texts circulate without their context", and that "they don't bring with them the field of production of which they are a product". Moreover, he argued, the recipients "are themselves in a different field of production, [and] re-interpret the texts in accordance with the structure of the field of reception". This perspective has been influential in recent research, in the

* I am indebted to Andrew Gordon, Sven Beckert, Gabriel Winant, Alyssa Bowen, the anonymous $I R S H$ readers, and especially to Rudi Batzell and David Mayer for the comments and remarks that contributed to the final version of this article.

I. Pierre Bourdieu, "The Social Conditions of the International Circulation of Ideas", in Richard Shusterman (ed.), Bourdieu: A Critical Reader (Oxford, 2002), pp. 220-228, 220. Note that Bourdieu, in 1989, was still talking of "international circulation", while today, following the changes in dominant attributes, he would most likely choose the attribute "transnational". 
"center" as well as the "peripheries", contributing to a more sophisticated view of the way in which ideas circulate over time and space. In a Spanish-language volume edited in Rosario, Argentina, almost a decade ago, Ricardo Salvatore similarly pointed out that "local conditions tend to affect decisively the chances of certain knowledge enterprises spreading and becoming established". ${ }^{2}$

Following such perspectives, this article will pay close attention to the context in which Thompson was read by labor historians in Argentina as a means to analyse how the country's historiography in that field was shaped over several decades. It will focus less on the fact that Thompson's production was read and discussed in Argentina, and more on the way in which his work was received. This article follows the influence of Thompson through different moments, each with specific characteristics in terms of political situations and ideological contexts. Since these shifting interpretations heavily marked Argentine labor historiography, an assessment of Thompson's reception offers a specific, but nonetheless valuable, perspective from which to understand major movements and changes in Argentine historiography as a whole. ${ }^{3}$ The focus on labor history - both in terms of history of laborers and labor movements - allows one to reconstruct these developments in a more specific way than analysing, for instance, the whole field of "social history" or, even broader, all fields in which Thompson might have had an impact. While many of the assessments made for labor history might be valid in equal or similar ways for other fields as well, especially in social history, they should not be taken as a pars pro toto - the full gamut of the reception accorded to E.P. Thompson's work in Argentina over time would need further study.

\section{LABOR HISTORIOGRAPHY IN ARGENTINA DURING THE TWENTIETH CENTURY}

The whole development of Argentine historiography, and especially of Argentine labor history, should be assessed in close relationship with the uneasy political and institutional scene that marked the country and left its imprint on academic research. Given the significant and early development of the labor movement in the country, a "militant historiography"

2. Ricardo Salvatore, Los lugares del saber. Contextos locales y redes transnacionales en la formación del conocimiento moderno (Rosario, 2007), p. I3. All translations from Spanish are mine.

3. For other, both older and more recent, attempts to summarize and evaluate the historiography of labor in Argentina, see Mirta Lobato and Juan Suriano, "Trabajadores y movimiento obrero: entre la crisis y la profesionalización del historiador", Entrepasados, 4-5 (I993), pp. 4I-64; Nicolás Iñigo Carrera, "La historia de los trabajadores", in Jorge Gelman (ed.), La historia económica argentina en la encrucijada. Balances y perspectivas (Buenos Aires, 2006), pp. 27 I-284; Juan Suriano, “¿Cuál es hoy la historia de los trabajadores en la Argentina?”, Mundos do Trabalho, I:I (2009), pp. 27-50. I will try to highlight here how tracking Thompson's reception can provide a useful key to re-examining this story. 
represented the first important tradition in the history of labor. Indeed, for a long period the field attracted little attention from scholars, and the first works on the subject were written by a handful of authors directly involved in the workers' movement. In a way, these works can be considered the first example of transnational circulation of historiographical production, since "militant" histories of the labor movement were certainly to be found in many other countries: Sidney and Beatrice Webb's books on the history of the British labor movement, Franz Mehring's history of the German Social Democratic Party, and Jean Longuet's history of the International are just a few examples. As a result, by the mid-twentieth century the major political currents of the Argentine left had produced their own accounts of the labor movement's history. At first, these reflections came in the form of short pamphlets or articles in periodicals, but later on several important books were published. Between the I930s and the I960s the anarchist Diego Abad de Santillán, the socialist Jacinto Oddone, the syndicalist Sebastián Marotta, and the communist Rubens Iscaro offered a history of the labor movement in terms of political rather than social history. ${ }^{4}$ Highly partisan, they presented a detailed account of trade union and party congresses and also dealt with the main cycles of strikes and class struggles. It was mainly a history of the leadership: less attention was paid to the history of the rank and file of the labor movement, let alone to the situation and everyday life of workers not involved in unions and politics.

The rise of Peronism as a momentous political phenomenon in the I940s and I950s had a major impact on local historiography. This was not only because most histories written by adherers to leftist parties would now show a nostalgic character, longing for a return to a past when their influence in the labor movement was stronger, but also because some new approaches to labor history began to be advanced by Peronist historians. ${ }^{5}$ A second moment in the militant historiography, nationalist in its approach, can therefore be found in this context. Most of these studies tended to consider the first stages of the labor movement, when either socialist, anarchist, or communist influence was predominant, as a period dominated by "exotic plants", alien to local traditions and badly adapted to the interests of a working class that had found its "genuine" representation only with the emergence of Peronism. The polemical

4. See, as examples for the work of each of these authors, Diego Abad de Santillán, La F.O.R.A.: ideología y trayectoria del movimiento obrero revolucionario en la Argentina (Buenos Aires, I933); Jacinto Oddone, Gremialismo proletario argentino (Buenos Aires, I949); Rubens Iscaro, Origen y desarrollo del movimiento sindical argentino (Buenos Aires, 1958); Sebastián Marotta, El movimiento sindical argentino. Su génesis y desarrollo, I857-1907 (Buenos Aires, I960).

5. See, among others, Alberto Belloni, Del anarquismo al peronismo. Historia del movimiento obrero argentino (Buenos Aires, 1960); Rodolfo Puiggrós, Historia crítica de los partidos políticos argentinos (Buenos Aires, 1956); Alfredo López, Historia del movimiento social y la clase obrera argentina (Buenos Aires, I97I). 
point against the leftist currents was certainly made, but analysis of historical sources was scarce and their contribution to labor history was modest. Their books were concerned mainly with assessments of the political positions of socialists, communists, and anarchists in order to develop a strong criticism of what was considered a "foreign" perspective that was unable to understand the national peculiarities of the country. Since they claimed that the labor movement had constituted itself during the Peronist years, they were ill-equipped to understand the complex process that led to the emergence of the working class in a much earlier period.

After the forced demise of Peronism, a process of revitalization took place between 1955 and 1966 in universities and academic institutions, and new trends gained ground in the social sciences. Under the impact of functionalism and modernization theories, new research was conducted in close relationship with other disciplines, such as sociology, economics, and political science. With Peronism still holding sway among major sectors of the working class, one of the main issues of this research was precisely how to explain its rise and persistence. The most famous contribution during these years was probably that of the Italian-born sociologist Gino Germani, who explained the emergence of Peronism as a consequence of the social changes among the working class that had taken place in the r930s. According to Germani, an "old working class", of mainly European origin and politically aligned with leftist currents, had been reshaped by the industrialization process and internal migration of the I930s, creating a new proletariat, less politically conscious and therefore "available" for Perón to recruit followers from among it. ${ }^{6}$ Highly polemical, Germani’s work influenced scholarship for a long period, contributing to the introduction of social and economic dimensions in a debate that hitherto had focused on the political struggle between different currents inside the labor movement. ${ }^{7}$

Another military coup, in 1966, led to a wave of repression against universities, causing the expulsion of several researchers and bringing this academic revitalization to an end. A few years later, in the context of the political radicalization of the late I960s and early i970s, open interest in labor history resurfaced. It was for the most part still marked by the style, intellectual frameworks, and concerns of the old militant histories. ${ }^{8}$

6. Gino Germani, Política y sociedad en una época de transición, de la sociedad tradicional a la sociedad de masas (Buenos Aires, I962).

7. These years also saw the reception of the French Annales school and the emergence of social history as a field within academic historiography. Calling itself nueva historia (new history), it was associated in the r 960 s with historians such as José Luis Romero and Tulio Halperín Donghi. On this current, see, for example, Eduardo J. Miguez, "El paradigma de la historiografía económicosocial de la renovación de los años '60, visto desde los años '90", in Fernando Devoto (ed.), La historiografía argentina en el siglo XX (Buenos Aires, 2006), pp. I95-2 I 9.

8. See, for instance, José Panettieri, Los trabajadores (Buenos Aires, 1967); José Ratzer, Los marxistas argentinos del 90 (Cordoba, I970); Jorge Solomonoff, Ideologías del movimiento obrero 
It was also during these years that Miguel Murmis and Juan Carlos Portantiero criticized Germani's interpretation of the origins of Peronism and proposed a different perspective that moved away from the idea of Perón as a manipulative leader of an inexpert working class, stressing the agency of the workers in their support of his regime. ${ }^{9}$ After the democratic interregnum of 1973-1976, a military dictatorship again unleashed a bloody repression against the labor movement and the political currents of the left. These were hard times for academic production as a whole and especially for those, like most people working in the field of labor history, who regarded themselves as politically committed historians. During those years, some contributions came from foreign scholars: while Hobart Spalding had already provided an important compilation of sources, during the I970s some key research was undertaken, including assessments of the anarchist movement and the Socialist Party, but also of the living and working conditions of the urban workers and the formation of the city of Buenos Aires. ${ }^{10}$

\section{THE 1980S: “LABOR” IN A NEW BOOM OF SOCIAL HISTORY IN ARGENTINA}

While Argentine labor historiography had undergone an important development of its own, its proponents became acquainted with the output of British Marxist historians only at the end of the r970s. Eric Hobsbawm constituted an exception to this, some of his books already having been translated by the late i 960 s and early i 970 s. ${ }^{\text {II }}$ A Spanish version of Thompson's The Making appeared only in 1977, when it was published in Barcelona under

y conflicto social (Buenos Aires, I971); Julio Godio, El movimiento obrero y la cuestión nacional. Argentina: inmigrantes asalariados y lucha de clases I880-1910 (Buenos Aires, I972).

9. Miguel Murmis and Juan Carlos Portantiero, Estudios sobre los orígenes del peronismo (Buenos Aires, I97I).

I0. Hobart Spalding, La clase trabajadora argentina. Documentos para su historia, I890-I9I2 (Buenos Aires, I970); Guy Bourdé, "La condition ouvrière à Buenos Aires à la fin du XIXe et au debut du XXe siècle”, Le Mouvement Social, 84 (1973), pp. 3-33; Charles Sargent, The Spatial Evolution of Greater Buenos Aires, Argentina, I870-1930 (Tempe, 1974); James Scobie, "Patterns of Urbanization in Argentina, I869-1914", Latin American Research Review, I0:2 (1975), pp. I32-I34; Richard J. Walter, The Socialist Party of Argentina, I890-1930 (Austin, 1977); Donald Weinstein, Juan B. Justo y su época (Buenos Aires, 1978); Gonzalo Zaragoza, "Anarchisme et mouvement ouvrier en Argentine à la fin du XIXe siècle”, Le Mouvement social, I03 (1978), pp. 7-30; Iaacov Oved, El anarquismo y el movimiento obrero en Argentina (Buenos Aires, 1978).

I I. Las revoluciones burguesas [The Age of Revolution, 1962] appeared in Madrid as early as 1964. Rebeldes primitivos [Primitive Rebels, 1959] was published in Spain in 1968. En torno a los orígenes de la revolución industrial (a compilation of three works on the origins of the Industrial Revolution) was published in Buenos Aires in 1971. Obviously, a publication in Spanish in (until 1976) Francoist Spain might not have meant actual accessibility for scholars in Latin America. While this issue cannot be addressed here, it is certainly worth further examination. 
the title La formación historica de la clase obrera: Inglaterra, $I 780-I 832$, in the politically revitalized context of post-Francoism. ${ }^{12}$ The encounter between Argentine intellectuals and new international trends took place therefore during the final years of the I970s and the beginning of the I980s - which is relatively early in comparison with other countries, even in Western Europe. ${ }^{13}$ One of the factors that contributed, in a paradoxical way, to this early encounter was the most recent military dictatorship in Argentina (1976-1983). On the one hand, many young scholars had to leave the country and finished their graduate studies abroad - mainly in Mexico, France, Britain, or the United States. On the other, small groups of researchers and academics who stayed in Argentina tried to maintain and develop their studies at new centers linked to small private universities and sometimes financed by foreign foundations.

The new generation of intellectuals that became acquainted with new historiographical trends did so in the context of a transition between the radicalized years of the first half of the I970s and the democratic experience that followed the demise of the military government in 1983 . The reception of British Marxism and other influences in both labor history and other fields of historiography has to be located, then, in the broader context of a political turn that an important group of Argentine and Latin American scholars and intellectuals was going through in the final years of the I970s. Many of these intellectuals had belonged to radical leftist organizations in the first half of the I970s, and were now moving away from these political allegiances towards a revalorization of parliamentary and democratic reforms inside capitalist societies. As far as Argentine groups are concerned, we can find a glimpse of the interests of this generation if we take a look at journals and magazines such as Punto de Vista, Controversia, or Ciudad Futura, and a couple of years later such political-cultural ventures as the "Club de Cultura Socialista" (Socialist Culture Club). ${ }^{\mathrm{I}}$

I 2. Compared with several other major languages, however, 1977 is not as late as it appears at first sight. Also in 1979 , following the success of the Spanish version of The Making, a compilation of five articles on eighteenth-century English society was published in Barcelona, under the title Tradición, revuelta y consciencia de clase. Estudios sobre la crisis de la sociedad preindustrial. It included articles that would become extremely popular among the Spanish-speaking Thompsonian audience, such as "Time, Work-Discipline, and Industrial Capitalism" (1967), "The Moral Economy of the English Crowd in the Eighteenth Century" (I97I), and "Eighteenth-Century English Society: Class Struggle without Class?" (1978). Miseria de la teoria [The Poverty of Theory, 1978] was published in Barcelona in $198 \mathrm{I}$.

I3. See, for instance, Thomas Lindenberger's article "From Structuralism to Culturalism: The Protracted German Reception of The Making of the English Working Class and its Actuality Reassessed From a Post-Cold War Perspective" in the present issue 6i: I of the International Review of Social History.

I4. For a recent assessment of the history of these cultural magazines and intellectual ventures, see Martina Garategaray, "Democracia, intelectuales y política. Punto de Vista, Unidos y La Ciudad Futura en la transición política e ideológica de la década del '80", Estudios, 29 (2013), pp. 53-72. 
This political shift can certainly be placed in the broader context of an international trend. The characteristic trait of its development in Argentina, however, was that this political reorientation was directed towards an almost century-old political formation, the Unión Cívica Radical (UCR), and towards Raúl Alfonsín, its presidential candidate in $1983 .{ }^{15}$ His victory in the I 983 presidential elections gave those intellectual groups political strength and offered important impetus to their institutional consolidation. In this context, many scholars who had been developing their intellectual activity in exile or in small private centers were able to make their way into public universities.

After 1983, social history in general and labor history in particular experienced an upswing (especially studies on the pre-Peronist period). While new researchers started to contribute to this field in different parts of the country, Buenos Aires and Rosario were the centers of this trend. Despite their differences, this new literature shared a number of features and represented an innovative renewal in the fields of labor history and social history in general. Overall, it contributed to enriching the knowledge of the social and cultural aspects of workers' lives. Labor history thus assessed not only their participation in strikes and political rallies, but also their everyday life, their living conditions, and their cultural experiences. This renewal certainly implied moving away from the institutional and political history that had prevailed in previous studies and brought Argentine historiography closer to international trends and debates. It remained, however, focused on what had happened in Argentina, and, in fact, mostly in Buenos Aires, while comparative studies with a broader perspective were not easy to find.

What were the main concerns of this new historiography? Analyses of the political and institutional history of the labor movement and the left were now scarce, even though Ricardo Falcón and Edgardo Bilsky published important works on this subject. ${ }^{16}$ The formation of labor markets did receive more attention, and Ofelia Pianetto and Hilda Sabato shed light on how, oriented towards agricultural production, the country's economic structure contributed to creating a labor market where mobility and temporary work played a key role. ${ }^{17}$ Fernando Devoto brought to the fore the importance of

I5. The UCR had its origins in the I890s and dominated politics between 1916 and 1930, when President Hipólito Yrigoyen was deposed in a military coup. However, the popular character of the party and its influence among workers had been damaged during the years of Perón's government, when the UCR sided with the conservative forces in a fierce struggle against Peronism. The 1983 presidential election was the first occasion on which the UCR was able to defeat the Peronist Party in open and free elections.

16. Edgardo Bilsky, La Semana Trágica (Buenos Aires, 1984) and La F.O.R.A. y el movimiento obrero (1900-1910) (Buenos Aires, 1985); Ricardo Falcón, Los orígenes del movimiento obrero (I857-I899) (Buenos Aires, 1984) and El mundo del trabajo urbano (I890-1914) (Buenos Aires, 1986).

17. Ofelia Pianetto, "Mercado de trabajo y acción sindical en la Argentina, I890-1922", Desarrollo Económico, 94 (1984), pp. 297-307; Hilda Sabato, "La formación del mercado de trabajo en Buenos Aires, I850-1880”, Desarrollo Económico, 96 (1985), pp. 561-592. 
assessing the immigration process, as well as the importance of mutual benefit societies based on ethnic and national origins that grouped many immigrants before the consolidation of trade unions. ${ }^{18}$ At the same time, the scope of research was widened through the analysis of urban and living conditions and the first studies focusing on women. ${ }^{19}$ British historians were certainly influential in this new social history (which, as said, was to a high degree focused on labor), and Thompson's work held a prominent place, as the study of urban workers in the first stages of capitalist development became one of the main topics of interest. It is not surprising that, in this context, The Making rapidly became a key reference. "Traditional" accounts of the labor movement's political history were severely criticized, and emphasis was put on exploring aspects previously neglected, from the working and living conditions of the poor, to urban development or the immigrants' communities and associations. Thompson's concept of "experience" seemed to be crucial for almost every new effort.

But how was this text read, as it "circulated without its context"? Thompson had written The Making as part of a process that made a generation of communists break with the party, criticizing the Stalinized version of Marxism that prevailed within the Communist Party of Great Britain. History was therefore a battlefield of a broader dispute with both theoretical and political implications. It is well-known that Thompson was engaging in an argument against simplified interpretations that claimed the formation of the working class was a matter of economic determination alone (an argument that, at the time, prevailed not only among adherents of official communism but also in modernization-theory-inspired social sciences and economic history). But if he was certainly taking on the dominant perspective within the Communist Party, it must not be forgotten that Thompson remained a political activist his whole life. Moreover, The Making was written not by someone who was solely (not even mainly) an academic scholar, but by someone who largely remained an outsider to academic centers and who was highly concerned with adult education among the labor ranks.

Things were different for the Argentine scholars who appropriated Thompson's book during the I980s. Firstly, no critique of economists and sociologists working within modernization theory was at the forefront - if anything, the aim was to build links with the scholarship of the social scientists of the i 960 . Secondly, there was less a discussion within different currents of the left about how to achieve radical social transformation, than

I8. See, for instance, Fernando Devoto and Gianfausto Rosoli (eds), La inmigración italiana en la Argentina (Buenos Aires, 1985 ).

19. Leandro Gutiérrez, "Condiciones materiales de vida de los sectores populares en el Buenos Aires finisecular", in AA.VV., De historia e historiadores. Homenaje a José Luis Romero (Mexico City, 1984), pp. 425-436; Diego Armus (ed.), Sectores populares y vida urbana (Buenos Aires, 1984); María del Carmen Feijoo, Las mujeres y la vida en las ciudades (Buenos Aires, I991). 
a wholesale critique of revolutionary organizations. Thirdly, this political critique was accompanied by a severe judgment of previous partisan and militant accounts of the labor movement's history.

In this context, it was certainly not Thompson's militant activity or his commitment to leftist politics that received attention, nor was there much interest in his emphasis on the radical political trends that lay behind the "making" of the working class. These aspects of his work were carefully put aside, and his continuous links with Marxism were eclipsed by his critique of Stalinism, taking the latter as synonymous with a tacit renunciation of the first. As in other countries, this generation of Argentine social historians focused on Thompson's questioning the existence of some kind of automatic "determination" between economic base and political-cultural superstructure. Some scholars, however, went further. Luis Alberto Romero, for instance, argued that the very notion of "working class" as a useful concept should be questioned. Indeed, in an article published in 1987 he proposed the concept "sectores populares" (popular sectors) as a more sophisticated and comprehensive term to understand the complexities of "subaltern" groups. Romero claimed that the "identity" of these "popular sectors" had changed over time, and should not be assessed in terms of class consciousness. In fact, he argued that in the last few decades of the nineteenth century and the first years of the twentieth, Buenos Aires workers had developed an "initial identity" that was "critical and nonconformist with the established order". In the interwar period, however, this identity was to lose ground to another one, "popular, conformist and reformist", stimulated by a "vast process of social mobility" that "blurred the outlines of the social strata". ${ }^{20}$

How can we explain and understand this intellectual shift? As early as 1982, an article had appeared in Punto de Vista, signed by PEHESA, the main center for social and labor history at the time, ${ }^{21}$ which made the political implications of the future historical research agenda clear. Despite the troubled political history of the country, marked by institutional instability, weak governments, and military coups, there must be, the PEHESA argued, "nests" of democracy in the Argentine past - and it was the historian's task to find them in order to strengthen the democratic experience that was then beginning anew. Those nests of democracy could

20. Luis Alberto Romero, "Los sectores populares en las ciudades latinoamericanas del siglo XIX: la cuestión de la identidad”, Desarrollo Económico, 106 (1987), pp. 201-222, 2 I 2-2 I 3.

2I. The Programa de Estudios de Historia Económica y Social Americana (Social and Economic American History Study Program, PEHESA) was composed of historians such as Luis Alberto Romero, Hilda Sabato, Juan Carlos Korol, and Leandro Gutiérrez. The PEHESA was created in I 977 as a small center for discussion and research linked to a private university and with some funding from the Ford Foundation. After the demise of the dictatorship, it was eventually incorporated into the structure of the Universidad de Buenos Aires. 
be found, the article claimed, in the many social, mutualist, cultural, and political institutions that had flourished among the "popular sectors" of the pre-Peronist period. The class character of many of those institutions and organizations - and the presence of class habits, class languages, class discourses, and class political programs - was thus overlooked in order to stress the way in which the "popular sectors" showed a somehow persistent "democratic" character, not based on an irreconcilable antagonism in terms of class. For the argument to make sense, upward social mobility and integration needed to be stressed more than class differentiation and class conflict. Not surprisingly, in this context "popular sectors" was preferred to "working class". ${ }^{22}$

Even though from its very title The Making made clear that its objective was to deal with the formation of the "working class" - not even "classes", as Thompson pointed out in the preface ${ }^{23}$ - this shift towards the use of "popular sectors" was effected without questioning Thompson's conclusions and perspectives, but rather by vindicating them as part of the same tradition. As two of the main historians of the PEHESA explained,

We found it necessary to find categories that fit social contexts in which industrial workers were not the hegemonic group among popular sectors. We learned a lot from historians such as Hobsbawm or Thompson. But we were cautious enough to avoid mechanical transpositions of their conclusions, drawn from European societies, to our case. The most notable characteristic trait of Buenos Aires society, its strong social mobility, and the even stronger expectations it brought about, conspired against the formation of strong and consistent class identities. ${ }^{24}$

In sum, as Agustín Nieto has recently noted, during this reception process a subtle shift was made in three directions: from "working class" to "popular sectors"; from "consciousness" to "culture"; and from "class struggle" to "social conflict". ${ }^{25}$ As a result, the new historians borrowed both Thompson's anti-structuralism and his critique of one-sided politically biased history of the political and institutional organizations of the labor movement, but not his vindication of a history committed to the cause of the oppressed, his defense of the concept of "class", or the importance he gave to the role of class struggle.

22. Programa de Estudios de Historia Económica y Social Americana, “¿Dónde anida la democracia?”, Punto de Vista, is (1982), pp. 6-10.

23. "Class, rather than classes, for reasons which it is one purpose of this book to examine." E.P. Thompson, The Making of the English Working Class (New York, I966), p. 9.

24. Leandro Gutiérrez and Luis Alberto Romero, Sectores populares, cultura y política: Buenos Aires en la entreguerra (Buenos Aires, 1995), p. is.

25. Agustín Nieto, “Los usos de E.P. Thompson en la historiografía 'argentina': un itinerario posible”, Rey Desnudo. Revista de libros, 2:3 (2013), pp. 370-391, 382-383. 


\section{HARD TIMES AND A NEW BEGINNING: AN ARGENTINE "EXCEPTIONALISM"?}

Despite its promising development after 1983 , labor history was to lose ground by the end of that decade. If, in the mid-I980s, "working class" had been replaced by "popular sectors", now also the concern with a broader history of popular classes was abandoned. When, much later in 2006, Juan Suriano assessed the development of labor historiography in the previous two decades, he drew a rather gloomy picture of the i 990 . He claimed that during the I990s labor historiography underwent a crisis that promoted "a massive flight of social historians towards political history". ${ }^{26}$ This trend resembled developments around the world. The crisis was related, according to Suriano, to the broader context of downturn that the labor movement and the left were experiencing at a global level, in the context of the fall of the Berlin Wall and the advance of neo-liberalism.

Suriano's remarks seem undisputable as far as the situation regarding labor historiography during the I990s is concerned. During those years, prominent historians such as Hilda Sabato and Luis Alberto Romero, while they continued to profess an adherence to social history, did indeed move away from the history of labor, and the same road was followed by many of their disciples. Some authors associated with the PEHESA group, such as Juan Suriano and Mirta Lobato, did continue researching the subject, and from the ranks of the left a handful of radical historians contributed to keep alive the history of the working class, like Nicolás Iñigo Carrera and the PIMSA group (Programa de Investigación sobre el Movimiento de la Sociedad Argentina, Research Program about the Movement of Argentine Society. ${ }^{27}$ And, like in the I970s, it was again a number of foreign scholars who made important contributions, especially in the case of the Americanbased historian Daniel James, who re-examined the history of labor struggles and Peronist unions in the I950s and I960s, highlighting the deep roots that Peronism was able to establish among sectors of the Argentine working class. ${ }^{28}$ Still, the I990s appear as a period when labor history and, once the

26. Juan Suriano, "Los dilemas actuales de la historia de los trabajadores", in Gelman, La historia económica argentina, pp. $285-306,289$.

27. In 1997, the creation of the Centro de Documentación e Investigación de la Cultura de Izquierdas en Argentina (CeDInCI - Center for Documentation and Research on Leftist Culture in Argentina) represented a significant milestone for promoting research on the history of contentious movements. The CeDInCI is a library and archive that holds a highly important collection of documents (newspapers, leaflets, letters, books, etc.) about the history of the left. Before its creation, research on the history of the labor movement and the left depended on the scarce material held by public libraries and private collections of former militants (or the International Institute of Social History in Amsterdam, for those who were able to make the trip).

28. Daniel James, Resistance and Integration: Peronism and the Argentine Working Class, 1946-1976 (Cambridge, 1988). A Spanish translation was first published in 1990. 
new, cultural-turn-inspired paradigms had also been adopted in Argentina, social history in general wandered in the wilderness, trying to carry on at the boundaries of the discipline.

Again, none of this was an Argentine peculiarity, as the "crisis of labor history" has been assessed many times and for many different countries. Interestingly, and quite dissimilar from academic trends in Europe, North America, and many other world regions, however, a turning point can be found with the beginning of the 2000 s. Closely related to the deep political and social crisis erupting in Argentina in 200I (to which I will return below), a new interest in assessing the history of the labor movement and other social movements awoke. In this revival it was noticeable that interpretations moved away from the historiography of the I 980 , in at least two directions. First, there was a renewed concern with studying the intervention of political currents inside the labor movement, an element that had been neglected in previous years. The analysis of the relationship between the labor movement and left currents contributed to show that the latter remained significant inside the working class despite the undisputable Peronist influence after the I940s. Thus, in a series of studies the agitated I960s and early i970s moved center stage. In 2000, Pablo Pozzi and Alejandro Schneider published Los setentistas, a book on the history of labor militancy during the I970s, which stressed the importance of the intervention of revolutionary activists in the labor movement's rank and file. In the same vein, in 200I, Pozzi published his history of the Guevarist Partido Revolucionario de los Trabajadores, a small but influential leftist party of the I960s and I970s. Schneider also wrote Los compañeros in 2005 , in which he examined the intervention of rank-and-file leftist activists inside the labor movement in the I960s, struggling against both state repression and trade-union bureaucracy. ${ }^{29}$

Second, the idea that class conflicts had been blurred in the interwar period was called into question. These studies insisted on the importance of going back to a study of labor struggles, especially strikes, and working-class politics. For instance, in 2000, Nicolás Iñigo Carrera edited La estrategia de la clase obrera: 1936, which shed light on the general strike of 1936 and has become the most significant work on the history of class struggles in the r93os. Iñigo Carrera's book made a substantial contribution to questioning the interpretation put forward by Luis Alberto Romero, who had argued that this period had been characterized by a buffering of class conflicts and class consciousness. His careful description of the general strike that shook Buenos Aires in the summer of 1936 showed an electrified city divided by class

29. Pablo Pozzi and Alejandro Schneider, Los setentistas. Izquierda y clase obrera (1969-1976) (Buenos Aires, 2000); Pablo Pozzi, Por las sendas argentinas: el PRT-ERP, la guerrilla marxista (Buenos Aires, 200I); Alejandro Schneider, Los compañeros: trabajadores, izquierda y peronismo, 1955-1973 (Buenos Aires, 2005). 
conflicts, very different from the story of upward social mobility and blurred class divisions that previous research had depicted. Iñigo Carrera explicitly criticized the "sectores populares" approach, argued that the "subject of history is social classes", and went on to claim that classes "were constituted in the process of struggle". His book was devoted, then, to examining "the struggles themselves, rather than the institutional forms (unions, parties, political alliances) that are an outcome of these struggles". ${ }^{30}$ In several articles, Iñigo Carrera acknowledged The Making's contribution in the field of labor history while, at the same time, criticizing what he considers, also in E.P. Thompson's work, an underestimation of economic determinations and class struggle episodes vis-à-vis the cultural, ideological, and political experiences of the working class. ${ }^{3 \mathrm{I}}$

Another important work was Hernán Camarero's history of the Communist Party during the I920s and I930s, published in 2007. He showed that the Communist Party had fostered the development of a "non-conformist and working-class communist identity" inside the labor movement. This development had been possible "inside and outside the workplace, through strikes and socio-cultural practices" and contributed to the creation of a "differentiated class personality, with a strong antagonistic component". ${ }^{2}$ Openly drawing upon Eric Hobsbawm's contributions on the history of labor and the left, Camarero also included references to E.P. Thompson's interventions in the debate about working-class living conditions during the British Industrial Revolution, when he stated that the I930s were a decade of hardship for Argentinian workers. ${ }^{33}$ Moreover, as they contributed to a reassessment of the situation of the labor movement in the I930s, both Camarero's and Iñigo Carrera's books stimulated new research on the origins of Peronism.

Marking a significant departure from the patterns of I980s labor and social history, the main topics at stake in the new research were directly related to the way in which the study of the working class should be interpreted and conceptualized. Indeed, in 200I, three historians of this generation addressed Thompson's influence in their work. They argued against the PEHESA historians' notion of popular sectors and vindicated the use of working class as one of Thompson's key contributions to social and

30. Nicolás Iñigo Carrera, La estrategia de la clase obrera: 1936 (Buenos Aires, 2000), p. I6. 3 I. See, for instance, idem, "La clase obrera en E.P. Thompson y en Karl Marx", Rey Desnudo. Revista de libros, 2:3 (2013), pp. $42 \mathrm{I}-430$.

32. Hernán Camarero, A la conquista de la clase obrera: los comunistas y el mundo del trabajo en la Argentina, 1920-1935 (Buenos Aires, 2007), pp. LV, LVII. Together with Carlos Herrera, Camarero edited a volume devoted to the history of the Socialist Party, also contributing to a reappraisal of the history of the links between labor and the left in relation to this other major current: Hernán Camarero and Carlos Herrera (eds), El Partido Socialista en Argentina: sociedad, politica e ideas a través de un siglo (Buenos Aires, 2005).

33. Camarero, A la conquista de la clase obrera, p. 58. 
labor history. Interestingly, they stressed an aspect of Thompson's work that had been neglected by previous scholarship: his political commitment. "He forced us", they argued, "to study history and socialism in a different way, placing freedom at the center of any socialist and revolutionary project". They criticized the labor historians of the 1980 s for "moving too far the boundaries of labor history and dissolving the category of working class". ${ }^{34}$ In the same vein, Pablo Pozzi argued in another article that he and other members of his generation had found in British Marxist historians "a fusion of theory and practice that made the work of the historian what we wanted it to be: a contribution to society, to the exploited, to the working class". ${ }^{35}$ This interpretation of Hobsbawm and Thompson as "militant intellectuals", as Pozzi argued, contrasted sharply with the model the PEHESA school had shaped in relation to the same historians.

Again, historiographical shifts need to be read in close conjunction with the political and social context. Pozzi, Camarero, and Schneider's article was published in 200I, a year that undoubtedly represented a turning point in recent Argentine history. In the midst of the worst economic crisis in the country's history, a massive popular movement - in many ways resembling the unrest of 20I I-20I3 in Egypt, Spain, Turkey, or Brazil - took to the streets against the government, leading to a major political crisis. In late December 200I, seven presidents held office within the space of just one week, incapable of controlling street mobilizations and unable to lead the crisis back onto institutional tracks. In the following months, "popular assemblies" flourished around the country, neighborhood "councils" composed mainly of the unemployed, workers, and impoverished middle-class men and women. The years that followed witnessed an upsurge of political activism, especially among the youth.

It is not surprising that in this context labor history again became an important field of academic research. In the country's most important regular gathering of historians, the Jornadas Interescuelas/Departamentos de Historia, at least fifteen per cent of the panels are currently devoted to the history of workers and the left in a broad sense. ${ }^{36}$ Scores of $\mathrm{PhD}$ dissertations, books, and even new journals devoted entirely to the history of labor have appeared in recent years. This new interest in the political history of the

34. Pablo Pozzi, Hernán Camarero, and Alejandro Schneider, "Eppur si muove. De la realidad a la conceptualización en el estudio de la clase obrera argentina", Taller. Revista de Cultura, Sociedad y Política, I6 (200I), pp. 190-2 I5, 201-202.

35. Pablo Pozzi, "Eric Hobsbawm: historia social e historia militante”, Espaço Plural, i6:I (2007), pp. 9-17, I0.

36. The event is attended by thousands of researchers, teachers, and both graduate and undergraduate students, as well as hundreds of scholars from foreign countries. In Catamarca, in $20 \mathrm{I}$ I, the event offered ninety-nine panels, while in Mendoza, two years later, there were I33. At each panel, an average of ten to fifteen papers is presented, though in some cases the figure can increase to twenty or twenty-five. 
labor movement and the left, which appears to constitute an Argentine "exceptionalism", needs to be assessed against the background of the importance that social movements have gained in Argentina - and in Latin America as a whole - in recent decades.

The two trends mentioned above continue to shape current research. On the one hand, it is possible to find a return to what was once called a "traditional" history of the labor movement and leftist organizations, in the sense that it deals with the political trajectories of groups, parties, and unions, and also assesses strikes and mass actions. This holds especially true for the history of labor and the left in the i 960 s and i 970 . Research in this field shows an expansion of geographical boundaries, as the history of leftist organizations in other Latin American countries, especially Chile and Bolivia, attracted the interest of a growing number of young researchers. In close conjunction with the history of the left in this period, an important set of studies emerged around the issue of exile and memory. They deal with the resistance to the military dictatorships in Argentina and Latin America during the I970s and early I980s. In many cases, these works assess the history of labor activism and leftist activities fighting repression and in defense of human rights, both in Argentina and abroad. On the other hand, the study of strikes and conflicts has been one of the most active fields of research, especially during the years of the first Peronist government (1946-1955) and during the convulsive years of the 1960s and the first half of the i 970 .

Gender studies, which gained momentum internationally during the I980s, struggled to make progress during the I990s and afterwards in Argentina. Following Joan Scott's influential studies, several historians contributed to integrating gender relations into Thompsonian frameworks highlighting that any collective is formed by different kinds of individuals, with uneven access to power and cultural, symbolic, and material goods. ${ }^{37}$ Researchers thus examined the role that women played in organizing their fellow rank-and-file factory workers, the lives and activism of female leaders, and also the role the labor movement organizations themselves assigned to women and to gender struggles over time. More recently, and similar to developments in other countries, gender studies has been established as a field of research of its own, thus shifting the focus away from the links between gender and class.

Despite their importance, less attention has been devoted to including ethnic and racial problems in broader labor studies. In fact, studies on these

37. See, among others, Mirta Zaida Lobato, Historia de las trabajadoras en la Argentina (I869-1960) (Buenos Aires, 2007); María Celia Bravo, Fernanda Gil Lozano, and Valeria Pita (eds), Historias de luchas, resistencias y representaciones: mujeres en la Argentina, siglos XIX y XX (Tucumán, 2008); Andrea Andújar et al., De minifaldas, militancias y revoluciones: exploraciones sobre los 70 en la Argentina (Buenos Aires, 2009). 
subjects are few, and few have provided links to general assessments on the formation of the working class. ${ }^{38}$ Even though this article has focused on the historiography of labor in the late nineteenth and in the twentieth centuries, it should be noted that in recent years earlier periods have also been studied by historians with an interest in labor issues. Indeed, in the field of rural and urban conflicts in colonial and early independent times it is possible to find explicit references to E.P. Thompson's interpretations of the role played by custom and law in shaping popular practices. ${ }^{39}$

It is probably still too early to attempt a broad characterization of the ongoing reconstitution and revitalization of the field, as different authors contribute with distinct points of view. Moreover, in many cases it is possible to find a dialogue among scholars of the different generations discussed here. ${ }^{4}$ What is certain, in any case, is that the history of the "working class" is now a common ground for these discussions and, more broadly, that Marxist concepts and frameworks again provide a shared language even among scholars with different political allegiances.

\section{FINAL REMARKS}

If we adopt a transnational perspective to assess the history of ideas, it is important to think in which ways historiography in different world regions can be shaped by multilateral influences. In the article by Ricardo Salvatore mentioned at the beginning, he poses a question highly relevant to those interested in the transnational circulation of ideas: "When and why", he asks, "does a body of knowledge become transnational and therefore seemingly 'out

38. For a discussion on this subject, see Ezequiel Adamovsky, Historia de las clases populares en la Argentina: desde I880 hasta 2003 (Buenos Aires, 2012). He decided to use the term "clases populares", which sounds very close to "sectores populares". Adamovsky, however, considers that those "popular classes" were shaped as a consequence of conflict, whereas the social historians of the 1980 s understood the making of the "popular sectors" as an outcome of the buffering of class antagonism.

39. For such explicit references see, for instance, Raúl Fradkin (ed.), El poder y la vara: estudios sobre la justicia y la construcción del estado en el Buenos Aires rural, I780-I830 (Buenos Aires, 2007), p. I 2, and Lyman Johnson, Workshop of Revolution: Plebeian Buenos Aires and the Atlantic World, $1776-1810$ (Durham, 20II), pp. 192-193. Further examples of labor-related studies on these periods are Raúl Fradkin (ed.), La ley es tela de araña. Ley, justicia y sociedad rural en Buenos Aires, $1780-1830$ (Buenos Aires, 2009); Juan Carlos Garavaglia, Pastores y labradores de Buenos Aires. Una historia agraria de la campaña bonaerense, I700-I 830 (Buenos Aires, I999). 40. Examples for this intergenerational dialogue are the seminars and workshops organized by Mirta Lobato at the Universidad de San Martín, gathering labor historians from different locations, perspectives, and generations, the conference on E.P. Thompson organized at the Universidad Nacional de Quilmes in June 2013 (with keynote speeches by Lobato and Nicolás Iñigo Carrera), and an intervention by Daniel James, "Los orígenes del peronismo y la tarea del historiador", published in the third issue (2013) of Archivos de historia del movimiento obrero y la izquierda, a new journal on the history of labor and the left, edited by Hernán Camarero in Buenos Aires. 
of nowhere' in particular?” E.P. Thompson's work and the influence of The Making seem perfect examples of such an enquiry: while The Making as an intellectual achievement was highly determined by a British context (and has, indeed, often been criticized for its provincialism), the book has been read and appropriated around the world. Following the trail of this book allows one to reveal the continuous remaking of The Making, which turned it into a global point of reference for historians in different places.

If texts and ideas circulate "without their context", then it is crucial to assess the concrete ways in which the reception of certain classic works took place and how they contributed to shape the development of historiography in different regions. In so doing, it seems obvious that local and national traditions cannot be understood without taking into account the global development of the field, while, at the same time, any assessment of global historiographical phenomena (and The Making belongs to these) needs to draw upon an analysis of the different contexts and peculiarities.

I have tried to highlight how, in the context of the I980s and the I990s, characterized by a crisis of the political left and a downturn in the labor movement, Thompson's appropriation was focused on his critique of Marxist "determinism". The concept sectores populares developed as a consequence of the alleged necessity of going beyond what was seen as a simplistic approach. While the latter corresponded to similar developments in other countries, Argentinian labor historiography started to diverge noticeably in the early 2000 s, when a tremendous social, political, and economic crisis shook the country. These years were marked not only by economic turmoil but also by a strong increase in labor and popular mobilization, as happened in many other Latin American countries. In these years, numerous historians of a younger generation started to defend (again) a different approach to Thompson's oeuvre - one that vindicated his political commitment and the use of working class as a rich and useful concept for the study of past struggles. This scholarship has decidedly moved away from the social history of the I980s. In this respect, in recent years the development of historiography in Argentina shows a pattern different from that seen in the Global North.

What remains to be seen is whether this turn of things is a peculiar local development or rather an anticipation of developments in the Global North both in terms of context (economic and social crisis afflicting Europe and the United States since 2008) and a revival of labor history. Labor history in these countries does indeed seem to have seen a revival. In this revival E.P. Thompson still has something to say to a new generation of students, certainly influenced by the political activism of recent years. The Argentinian "exceptionalism" might, in future assessments, therefore appear less as a divergent path and more as an early example of a more general trend in another wave of re-reading (and thus re-making) The Making. 


\section{TRANSLATED ABSTRACTS \\ FRENCH - GERMAN - SPANISH}

Lucas Poy. En refaisant The Making: la réception d'E.P. Thompson en Argentine et le façonnement de l'historiographie du mouvement ouvrier.

Cet article retrace la réception de l'œuvre d'E.P. Thompson en Argentine durant les trois dernières décennies. Il étudie le contexte dans lequel les historiens du mouvement ouvrier lurent Thompson comme moyen d'analyser la manière dont l'historiographie ouvrière de l'Argentine se façonna au cours de cette période. L'article soutient que, dans les années 1980 et 1990 , par rapport à un contexte caractérisé par une crise de la gauche politique et un déclin dans le mouvement ouvrier, l'appropriation de Thompson se concentra sur sa critique du "déterminisme" marxiste. Cette évolution est parallèle à des développements analogues dans d'autres pays, mais l'historiographie ouvrière argentine commença à emprunter une autre voie au début des années 2000, lorsqu'une terrible crise sociale, politique et économique ébranla le pays. L'article conclut que les développements récents dans l'historiographie ouvrière en Argentine présente un modèle différent de ceux connus dans le "Nord mondial".

Traduction: Christine Plard

Lucas Poy. Die fortlaufende Neu-erarbeitung von The Making: E.P. Thompsons Rezeption in Argentinien und die Prägung der Arbeitsgeschichte.

Dieser Beitrag rekonstruiert die Rezeptionsgeschichte E.P. Thompsons in Argentinien während der vergangenen drei Jahrzehnte. Er erkundet den Kontext, innerhalb dessen Thompson von Arbeitshistorikern gelesen wurde, um auf diesem Weg die Entwicklung der Arbeitsgeschichte des Landes in dieser Zeit zu analysieren. Es wird die These vertreten, dass die Aneignung Thompsons in den r980er und I 990er Jahren, die von einer Krise der politischen Linken und einer Schwächung der Arbeiterbewegung geprägt waren, auf dessen Kritik des marxistischen "Determinismus” fokussiert war. Während dies noch vergleichbaren Entwicklungen in anderen Ländern entsprach, begann die argentinische Arbeitsgeschichte in den 2000er Jahren, als das Land von einer gewaltigen sozialen, politischen und Wirtschaftskrise erschüttert wurde, einen eigenen Weg zu beschreiten. Der Beitrag endet mit der Beobachtung, dass jüngere Entwicklungen innerhalb der argentinischen Arbeitsgeschichte von den aus dem "globalen Norden” beobachtbaren abweichen.

Übersetzung: Max Henninger

Lucas Poy. Reformando The Making: E.P. Thompson en Argentina y la configuración de una historiografía obrera.

Este artículo se centra en la recepción en Argentina de los trabajos de E.P. Thompson a lo largo de las tres últimas décadas. En él se explora el contexto en el que Thompson fue leído por los historiadores del trabajo como una vía de análisis de la forma en que 
la historiografía obrera argentina se fue configurando a lo largo de ese periodo. Se sostiene que, en las décadas de 1980 y I990, en un contexto caracterizado por una crisis política de la izquierda y por una pronunciada caída del movimiento obrero, la apropiación de Thompson se centró en su crítica del "determinismo" marxista. Mientras este aspecto es un elemento similar a lo que se ha podido observar en otros países, la historiografía obrera argentina comenzó a mostrar una trayectoria distinta en los inicios de la década del 2000, cuando una tremenda crisis social, política y económica sacudió el país. El artículo concluye que el desarrollo reciente de la historiografía obrera en Argentina se configura como un modelo distinto al que existe en otros espacios del "norte global".

Traducción: Vicent Sanz Rozalén 